\title{
Sovereign immunity and its implications for neurosurgery
}

\author{
Rimal H. Dossani, MD, ${ }^{1}$ Muhammad Waqas, MBBS, ${ }^{2}$ Michael J. Meyer, BS, ${ }^{3}$ Felix Chin, BS, ${ }^{2}$ \\ Hamid H. Rai, MBBS, ${ }^{2}$ Rameez Dossani, JD, ${ }^{4}$ Anshara Munir Dossani, JD, ${ }^{5}$ and \\ Muhammad Riaz, MD ${ }^{6}$
}

\begin{abstract}
${ }^{1}$ Department of Neurosurgery, Louisiana State University, Shreveport, Louisiana; ${ }^{2}$ Department of Neurosurgery and ${ }^{3}$ Jacobs School of Medicine, University at Buffalo, New York; ${ }^{4}$ Robert H. McKinney School of Law, Indianapolis, Indiana; ${ }^{5}$ St. Thomas University School of Law, Miami Gardens, Florida; and ${ }^{6}$ Department of Neurosurgery, University of Colorado, Denver, Colorado
\end{abstract}

The proportion of neurosurgeons facing a malpractice suit each year is highest among all medical and surgical specialties. It is critical for neurosurgeons to understand local malpractice laws because they vary among states. Sovereign immunity, as described in the 11 th constitutional amendment, provides absolute immunity to states from being sued by their residents and by other states. A state may waive its sovereign immunity, however, and substitute itself as the defendant in place of a state-employed physician in the court of law. This means that a physician working for a statefunded hospital may not be liable to a malpractice suit. Further provisions of the law allow the state not to pay indemnity beyond a certain limit, which discourages plaintiff attorneys from pursuing indemnity charges against physicians working for state-funded institutions. In this review, the authors describe the concept of sovereign immunity and its implications for the practice of neurosurgery.

https://thejns.org/doi/abs/10.3171/2020.8.FOCUS20613

KEYWORDS malpractice; neurosurgery; sovereign immunity law; liability

$\mathrm{T}$ HE proportion of neurosurgeons facing a malpractice claim each year is $19.1 \%$, which is higher than any other specialty in medicine or surgery. ${ }^{1}$ The mean indemnity payment is approximately $\$ 350,000$ for neurosurgeons, which is significantly higher than that of $\$ 275,000$ for physicians across all specialties. ${ }^{1,2}$ Rising malpractice premiums and fear of indemnity payments have forced neurosurgeons to shy away from complex cases, restrict their practices, or consider early retirement. The rationale for holding physicians accountable for injury to patients is that they will practice safer and higherquality medicine. A systematic review, however, found no association between malpractice liability and healthcare outcomes and quality. ${ }^{3}$

A US state's sovereign immunity, simply stated, is the immunity of a state from being sued by other states or by citizens within or outside that state. Although a state holds sovereign immunity, it may sometimes choose to waive this immunity. When a state-funded hospital and/ or its employees are faced with a medical malpractice suit, the state can waive its sovereign immunity and replace the initial defendant(s) with itself in the malpractice suit. Further provisions of the law allow the state not to pay indemnity beyond a certain limit.

Neurosurgeons practicing in states that waive their sovereign immunity have significant protections in the arena of malpractice liability. In this review, we describe the principle of sovereign immunity and its implications for the practice of neurosurgery.

\section{Methods}

This study is a descriptive review of the literature. We searched PubMed and Google Scholar for articles that describe the principle of sovereign immunity relating to malpractice liability in medical practice and neurosurgery.

\section{Results}

\section{Sovereign Immunity and Its Waiver}

The principle of sovereign immunity is derived from British law with the precept that the "King can do no wrong" and therefore cannot be sued in his own court. ${ }^{4}$ The 11th amendment of the Constitution of the United States was adopted to prevent states from being sued by other states or citizens within other states. This immunity was expanded in 1921 by the US Supreme Court to include the barring of citizens from suing their own state. However, states have the right to waive their sovereign immunity. 5,6 When this occurs, a physician working for a state-funded hospital may not be liable to a malpractice suit. ${ }^{6}$ Instead, the state may waive its sovereign immunity and substitute 
itself as the defendant in place of the physician in the court of law. Further provisions of the law allow the state not to pay indemnity beyond a certain limit, which discourages plaintiff attorneys from pursuing indemnity charges against physicians working for state-funded institutions.

\section{The Federal Tort Claim Act}

The Federal Tort Claim Act was passed in 1946. The federal law was meant to provide protection to physicians working for the military on foreign soil. Under the law, physicians cannot be sued individually. Instead, the federal government will act as defendant in these cases on the behalf of physicians, because under the law "the government allows itself to be sued for the acts of its departments, agencies, and employees to the same extent as a private individual for inappropriate acts under negligence law."

\section{Florida Statute Section 768.28}

The state in which neurosurgeons practice determines what protections they receive from their state government as defendants in a malpractice claim. In states that waive their sovereign immunity, physicians employed at public or government institutions are protected from malpractice lawsuits through defendant substitution, whereby the public entity takes the place of the individual physician as the defendant.

For example, Florida has waived its sovereign immunity so that employees of a nonprofit college or university operating a medical school with an affiliated teaching hospital are viewed as acting on behalf of a public agency and are thus protected from personal liability via defendant substitution (Florida Statute §768.28). Florida law also prohibits naming an individual physician as the defendant when the public entity has already been substituted as the defendant, and the law limits indemnity amounts payable by the state to $\$ 200,000$ per claimant and $\$ 300,000$ total. The statute stipulates that the physician will be granted these additional protections as long as the actions under dispute were made without malicious intent or blatant disregard for human rights or safety. The following summarizes the Florida statute:

- Florida law prohibits specifically naming the healthcare provider in the lawsuit if the state/hospital/public trust substitutes for the defendant.

- "[W]hen an employee of a University negligently causes personal injury, sovereign immunity is waived, subject to limitations, and the injured party may assert a claim or file a lawsuit against the University."

» "However, healthcare providers are provided immunity from personal liability while acting as an employee of the University not in bad faith or with malicious intent or willful disregard for human rights or safety."

» "[T]he provider will not be held responsible personally for any money damages that might result from the claim or lawsuit."

» The provider loses his or her immunity if their act is grossly negligent.

- The law also limits the amount payable by the state in these cases to $\$ 100,000$ per claimant, and total amount (regardless of number of claimants) to $\$ 200,000$.

» These amounts were increased to $\$ 200,000$ and $\$ 300,000$ (respectively) in 2010 .

- The law applies to all healthcare providers (resident physicians, attending physicians, and midlevel providers [physician assistants and nurse practitioners]).

The Florida Department of Health can still investigate acts of negligence and revoke the provider's license regardless of sovereign immunity. Also, the hospital administration can issue sanctions.

\section{Discussion}

According to Jena et al., 19.1\% of US neurosurgeons face a malpractice claim each year, making neurosurgery the specialty facing the most malpractice claims annually of the 25 specialties examined in their study. ${ }^{8}$ Many of these claims do not result in indemnity payments to the plaintiff. However, many physicians still feel pressure to practice defensive medicine (ordering tests and procedures primarily to defend oneself in a lawsuit, which drives up healthcare costs) and fear increasing malpractice insurance premiums. ${ }^{1,9}$

Elsamadicy et al. analyzed 2131 malpractice cases filed between 2003 and 2012 in which a neurosurgeon was the primary defendant. ${ }^{2}$ The authors found that improper performance by the neurosurgeon was the reason for the suit in $42.1 \%$ of cases. Six of the seven medical conditions most frequently resulting in a lawsuit fell within the spine subspecialty. This can partially be accounted for by the high number of cases performed by spine surgeons. In addition, the elective nature of many spine surgeries and the low expectations of possible complications by patients and their families may contribute to the high number of malpractice claims in the subspecialty. ${ }^{2}$ Neurosurgery was found to have the highest average indemnity payment $(\$ 439,146)$ when compared with the other 27 specialties included in that study. ${ }^{1}$ Interestingly, this amount is higher than the maximum limit of indemnity allowed by the state of Florida under Florida Statute Section 768.28(10)(f).

Thomas et al. investigated 343 malpractice jury verdicts delivered between 1985 and 2015 in which a neurosurgeon was the defendant. ${ }^{10}$ Less than $55 \%$ of malpractice cases against physicians progress to trial by jury. . $^{10,11}$ Therefore, the data in this study only represent a fraction of all claims made against neurosurgeons. Regardless, the states with the most claims were Florida (25.4\%), California (24.5\%), New York (11.1\%), Texas (7.9\%), and Illinois $(4.7 \%) .{ }^{10}$

State malpractice laws have a huge impact on neurosurgical practice. According to a survey by Nahed et al., $71 \%$ of neurosurgeons stated that medical liability concerns influence their preferred geographic location of practice. ${ }^{9}$ Due to a lack of protection, neurosurgeons have a tendency to opt out of complex neurosurgical procedures. States like Florida that implement a cap on damages provide neurosurgeons with an avenue to perform procedures that they may shy away from if they practiced in a state that did not have the same protections. Citizens who reside in states such as Alabama, Arizona, Arkansas, California, Connecticut, Delaware, Michigan, 
Nebraska, New Jersey, New York, Ohio, South Dakota, and Washington, which have no cap on damages in a malpractice lawsuit, may not find similar care. This situation overall promotes the practice of defensive medicine, forcing neurosurgeons and other physicians to order unnecessary investigations and workups, driving the cost of care much higher. This also puts neurosurgeons in private practice at a disadvantage, potentially forcing them out of practice. Among neurosurgeons, there is a growing trend toward choosing no longer to operate, along with a trend toward early retirement.

The importance of sovereign immunity goes beyond mere monetary implications. This immunity allows physicians, especially neurosurgeons, to perform their duties to the best of their ability without constantly fearing a lawsuit. Furthermore, not only is sovereign immunity beneficial for physicians, but also it allows members of society access to competent healthcare who otherwise could not afford it.

\section{Landmark Cases}

The notion of sovereign immunity, as complex as it may be, can be illustrated simply by describing two cases from Florida. The first case involves a woman who filed a medical negligence claim against doctors who allegedly did not perform a cesarean section in a timely manner. The woman visited doctors at a university hospital for prenatal care. During her prenatal visits between January and June, the woman presented with indications of preeclampsia. Those indications continued to be present on June 12, when she was finally prescribed medication. Because indications of preeclampsia continued the next day, the woman was admitted to the hospital. Her son was born 1 day later and "required aggressive resuscitation to include stimulation, suctioning and placement on CPAP" (a continuous positive airway pressure machine).

The infant was "limp and suffering significant respiratory failure, requiring intubation." "[A] head ultrasound revealed grade II intraventricular hemorrhage consistent with an anoxic/hypoxic injury." The infant died on the evening of his birth (case no. 14-17565 [Fla. 11th Cir. Ct.]).

On behalf of herself and her son, the woman sued the university and her doctors for medical negligence. The university and doctors moved to dismiss the complaint because they were "immune from suit under Sections 768.28(9)(a) and 768.28(10)(f), Florida Statutes, as agents of the Public Health Trust of Miami-Dade County d/b/a-Hospital." The woman, now plaintiff, argued in response that Sections 768.28(9) and 768.28(10)(f) violated the Florida Constitution, because the sections were unauthorized extensions of sovereign immunity to a private enterprise; violated her rights to equal protection and due process; improperly used the state's taxing power and credit for a private enterprise; and were impermissible special laws.

The circuit court found that the doctors were individuals entitled to immunity from suit under Florida Statute Sections 768.28(9) and 768.28(10)(f) (case no. 14-17565 [Fla. 11th Cir. Ct.]).

In the second case, a man filed suit in August 2015 against the same university and its employee, seeking damages for injuries suffered from surgery performed at the university hospital. The surgeon performed an embolization procedure, despite evidence that the patient did not wish it. As a result of the surgery, the man was blinded in his right eye.

The circuit court concluded that " $[\mathrm{t}] \mathrm{he}$ undisputed facts establish that Defendants, a ... School of Medicine faculty member, and the University itself, fall under the ambit of Fla. Stat. Secs. 768.28(9) and (10)(f)" and are therefore "entitled to sovereign immunity" (case no. 15-22968 [Fla. 11th Cir. Ct.]).

The cases were consolidated upon appeal. On appeal, the counsel for the plaintiffs in the two cases described above argued that immunity protection was unconstitutional and violated their client's equal protection rights.

The Third District Court of Appeals of Florida determined the following:

There is no factual dispute that the university and its employees and agents met the requirements of sections 768.28(9)(b) and (10)(f). The parties agree that the university is a "nonprofit independent college or university located and chartered in this state which owns and operates an accredited medical school." The parties agree that [University Hospital] is a teaching hospital. The parties agree that the university and the trust entered into an affiliation agreement. And the parties agree that university employees and agents performed patient services at [the hospital]... pursuant to the affiliation agreement.... The issue in this case, then, is not whether the university and its doctors met the requirements of sections 768.28(9)(b) and (10)(f). They did. Instead, the issue is whether sections 768.28(9)(b) and (10)(f) violate the Florida Constitution. Can the legislature constitutionally expand immunity to the university and its employees and agents?

SC18-1432, 2018 (Fla. Dec. 5, 2018), and review denied, SC18-1476, 2019 (Fla. Apr. 5, 2019)

Ultimately, the Third District Court of Appeals of Florida found, "[t]he legislature's 2011 amendments to section 768.28, contained in subsections (9)(b) and (10)(f), did not violate the sovereign immunity, equal protection, due process, access to courts, jury trial, and private debt provisions of the Florida Constitution."

In another case, the Second District Court of Appeal of Florida reasoned that sovereign immunity is

\begin{abstract}
[e]ffective in allowing doctors to obtain immunity from malpractice suits without sacrificing the income of private practice. If this method works, then economically it may be logical for many local physicians to join the nonprofit group. It might also be logical for many local patients to seek health care in nearby counties where doctors remain personally and professionally responsible to the patients and liable for negligence based upon the usual, reasonable levels of patient care.
\end{abstract}

884 So. 2d 257, 260 (Fla. Dist. Ct. App. 2004)

\section{Malpractice Liability During the COVID-19 Era}

Malpractice tort laws are dynamic. In the spring of 2020, the world faced the COVID-19 pandemic. Healthcare teams and hospitals found themselves understaffed and running low on supplies at the onset of the outbreak. With these increased stresses on healthcare providers in mind, the State of New York passed the Emergency or Disaster Treatment Protection Act. This 
expanded immunity to clinicians in nearly all of the healthcare facilities throughout the state as long as they were in some way involved in the COVID-19 response and did not act in a negligent manner (https://www.nysenate. gov/legislation/laws/PBH/A30-D). Thus, based on special circumstances, a state can extend or retract sovereign immunity protections. It is best for neurosurgeons to be aware of and stay up to date on the laws of the state in which they practice and how those laws may affect them if they find themselves in a malpractice suit.

\section{Conclusions}

Sovereign immunity law has significant implications for neurosurgical practice. A neurosurgeon must be aware of local malpractice laws. Since there is no significant evidence showing that increased liability improves clinical practice, an expansion of existing sovereign immunity laws may guard against defensive medical practices and potentially reduce the cost of healthcare delivery.

\section{References}

1. Mello MM, Chandra A, Gawande AA, Studdert DM. National costs of the medical liability system. Health Aff (Millwood). 2010;29(9):1569-1577.

2. Elsamadicy AA, Sergesketter AR, Frakes MD, Lad SP. Review of neurosurgery medical professional liability claims in the United States. Neurosurgery. 2018;83(5):997-1006.

3. Mello MM, Frakes MD, Blumenkranz E, Studdert DM. Malpractice liability and health care quality: a review. JAMA. 2020;323(4):352-366.

4. Akula JL. Sovereign immunity and health care: can government be trusted? Health Aff (Millwood). 2000;19(6):152-167.

5. US Constitution Annotated. Amendment XI. Suits Against Sates. State Sovereign Immunity. Accessed September 14, 2020. https://www.law.cornell.edu/constitution-conan/ amendment-11/state-sovereign-immunity

6. Suk M. Sovereign immunity: principles and application in medical malpractice. Clin Orthop Relat Res. 2012;470(5): $1365-1369$.

7. Peck CJ. Absolute liability and the Federal Tort Claims Act. Stanford Law Rev. 1957;9:433-454.
8. Jena AB, Seabury S, Lakdawalla D, Chandra A. Malpractice risk according to physician specialty. $N$ Engl J Med. 2011; 365(7):629-636.

9. Nahed BV, Babu MA, Smith TR, Heary RF. Malpractice liability and defensive medicine: a national survey of neurosurgeons. PLoS One. 2012;7(6):e39237.

10. Thomas R, Gupta R, Griessenauer CJ, et al. Medical malpractice in neurosurgery: a comprehensive analysis. World Neurosurg. 2018;110:e552-e559.

11. Jena AB, Chandra A, Lakdawalla D, Seabury S. Outcomes of medical malpractice litigation against US physicians. Arch Intern Med. 2012;172(11):892-894.

\section{Disclosures}

The authors report no conflict of interest concerning the materials or methods used in this study or the findings specified in this paper.

\section{Author Contributions}

Conception and design: RH Dossani, Riaz. Acquisition of data: RH Dossani, Waqas, Meyer, Rai, Riaz. Analysis and interpretation of data: RH Dossani, Waqas, Meyer, Chin, AM Dossani, Riaz. Drafting the article: RH Dossani, Waqas, Meyer, Chin, R Dossani, Riaz. Critically revising the article: RH Dossani, Waqas, Chin, Rai, R Dossani, AM Dossani, Riaz. Reviewed submitted version of manuscript: RH Dossani, Chin, Rai, R Dossani, AM Dossani. Approved the final version of the manuscript on behalf of all authors: RH Dossani. Statistical analysis: RH Dossani. Administrative/technical/material support: RH Dossani, Rai. Study supervision: RH Dossani, Riaz.

\section{Correspondence}

Rimal H. Dossani: Louisiana State University, Shreveport, LA. rimalh@gmail.com. 